\title{
Assessment of Anti-inflammatory and Anti-Proliferative Potential of Euphorbia hirta Roots: An in vitro Analysis
}

\author{
Rashmi Wadhwa*, Pankaj Gupta \\ Department of Pharmacy, School of Medical and Allied Sciences, K. R. Mangalam University, Sohna Road, Gurugram, Haryana, INDIA.
}

\begin{abstract}
Background: The current study focuses in vitro anti-inflammatory and anti-proliferative evaluation of the alcoholic extract of euphorbia hirta roots. Anti-inflammatory potential was screened by incorporating inhibition of protein denaturation assay and anti-proliferative potential by MTT assay. Methods: Anti-inflammatory potential of extract was evaluated by calculating the percentage inhibition of protein denaturation and anticancer activity of the alcoholic extract was assessed by evaluating the cell viability. Alcoholic roots extract of euphorbia hirta was treated with MCF - 7 cell lines and cell viability was determined at the wavelength of $570 \mathrm{~nm}$ by MTT method. Results: The results suggested the significant anti-inflammatory potential as it effectively inhibits the protein denaturation. The alcoholic roots extract of euphorbia hirta also showed anti-proliferative effect against MCF - 7 celllines $(p \leq 0.05)$ in a dose dependent manner. Conclusion: The root extract showed potential anti-inflammatory and anti-proliferative potential. As from
\end{abstract}

the results, it was concluded that extract had capability to constrain the propagation of cancer cells. Therefore, it appears to be a virtuous contender to provide protection against growth of tumour cells.

Key words: Euphorbiaceae, Medicinal plants, Phytoconstituents, Anticancer, Protein denaturation.

\section{Correspondence}

Rashmi Wadhwa,

Department of Pharmacy, School of Medical and Allied Sciences, K. R. Mangalam University, Sohna Road, Gurugram-122003, Haryana, INDIA.

Email id: rashmi1985.rw@gmail.com;

ORCID: 0000-0001-8348-9099

DOI: $10.5530 /$ ijpi.2021.4.79

\section{INTRODUCTION}

To save people from the grasps of ailments is a responsibility blessed and necessary from the time immemorial. Herbal plants are cast-off in management or as a counteractive effect since ancient ages. ${ }^{1,2}$ In India, use of the various parts of many herbal plants to treat various ailments has been in trend from ancient times. ${ }^{3}$ Genus Euphorbia from family Euphorbiaceae contains many important herbal medicinal plants. Plants which belongs to the family Euphorbiaceae has been found to contain compounds like flavonoids, alkaloids and triterpenoids by means of intense phytochemical screening. Euphorbia hirta belongs to the genus Euphorbia (Family - Euphorbiaceae). It is a slender-stemmed, twelvemonthly hairy plant; grow up to a length of $40 \mathrm{~cm}$ in height. Euphorbia hirta has a separate and developed primary root i.e. tap root system. ${ }^{4}$ In traditional indigineous system of medicine, Euphorbia hirta is widely used for the management and prevention of various bronchial and respiratory diseases. ${ }^{2,5}$ In spite of usage in bronchial and respiratory diseases, it is also used as antipyretic, anxiolytic, antifertility and analgesic herb. ${ }^{2}$ Many researchers have done phytochemical screening of Euphorbia hirta and it is testified to contain flavonoids like quercitin, afzelin, myricitin, euphorbin-A, euphorbin-B, shikmic acid, kaempferol and gallic acid. ${ }^{2,6}$

Inflammation is a procedure in which cells of human body protect them from infection caused by outside infectious agents, like bacteria. Inflammation is generally considered to be of two types. First one is acute inflammation and second is chronic inflammation. ${ }^{7,8}$ Protein denaturation has been correlated with the development of inflammatory disorders like arthritis, diabetes and cancer. Herbal anti-inflammatory agents are being explored as a potential alternative to synthetic drugs depending upon the presence of various types of phytoconstituents like flavonoids, alkaloids, glycosides, terpenoids and resins. ${ }^{9}$
Cancer is a disease in which cells and tissues of body grow abnormally. For proper functioning of a body, a strictly regulated cell growth is required. Cancerous cells continue to divide and multiply at abnormal speed, producing tumours. Benign tumours are the tumours which do not spread elsewhere in the body. Malignant tumour are the tumours which can enter the other tissues of body as well as can carry on to the other parts of body, if not get treated on time. ${ }^{10,11}$ Breast cancer is the cancer which is normally found in one in four cancers detected in women. The exact reason behind the cause of breast cancer is still not identified. In contemporary medicine, the chief treatments available for cancer include chemotherapy, radiotherapy and surgery. Although many chemotherapeutic drugs are accessible, but as they produce undesirable adverse effects as well as they are extremely expensive. ${ }^{12,13}$ Therefore, there is a significant curiosity in finding of new herbal agents which are effective against cancer. Some chemical constituents, that are present within the plant have evidenced cyanogenetic effect on these cancer cells and have no other side effects also. So, they possibly will be reflected as prominent anti - proliferative representatives to treat cancer. ${ }^{14,15}$ Although, many studies are done on Euphorbia hirta. Most of the studies were performed with the complete plant or leaves and few of them were performed on the separated components of the plant. ${ }^{2}$ Accordingly this study was completed with an objective to evaluate the anti-inflammatory and anti-proliferative potential of Euphorbia hirta root extract via in vitro measures. In vitro studies are essential to make therapeutic developments. It cannot perform the whole thing which in-vivo studies can do, but it can perform a lot. Thus in-vitro research is significant across all the arenas of medical research. For assessment of anti-inflammatory activity, protein denaturation inhibition assay was performed and activity was compared with diclofenac sodium as standard. For

This is an open access article distributed under the terms of the Creative Commons Attribution-NonCommercial-ShareAlike 4.0 License, which allows others to remix, tweak, and build upon the work non-commercially, as long as the author is credited and the new creations are licensed under the identical terms. 
anti-proliferation potential, MTT test was performed to grasp the capability of this plant for use in herbal medicine.

\section{MATERIALS AND METHODS}

\section{Collection of Plant material}

Euphorbia hirta root was collected from Palwal, Haryana, India, in the month of November, 2018. Identification and authentication was done by senior principal scientist of CSIR-NISCAIR and a plant specimen voucher was available with Raw Material Herbarium and Museum (RHMD).The root was cleaned thoroughly with distilled water to remove any type of contamination.

\section{Extraction of Plant material by soxhlet method}

The shade dried root was powdered by using dry grinder and passed through sieve. The root powder was packed properly into soxhlet apparatus and extracted successively with alcohol. This procedure was continued nonstop until the solvent in the thimble converts transparent. A semisolid product was produced when extract was evaporated in a rotary evaporator under reduced pressure and was stored in a refrigerator in airtight container below $10^{\circ} \mathrm{C} . .^{16,17}$

\section{Anti-inflammatory activity}

Protein denaturation inhibition assay: A test solution was made by adding $0.5 \mathrm{ml}$ of Bovine albumin serum ( $5 \% \mathrm{w} / \mathrm{v}$ aqueous solution) to $0.05 \mathrm{ml}$ of extracts at various concentrations varied from 100 to 1000 $\mu \mathrm{g} / \mathrm{ml}$. Test control was made by using $0.05 \mathrm{ml}$ of distilled water instead of extract and product control contains only different concentrations of extract and distilled water. $1 \mathrm{~N}$ hydrochloric acid was accustomed change the $\mathrm{pH}$ of all the solutions to 6.4 and all the reaction mixture was incubated at $37^{\circ} \mathrm{C}$ for $20 \mathrm{~min}$ and heated at $70^{\circ} \mathrm{C}$ for $5 \mathrm{~min}$. Once cooling the samples, the turbidity was measured using spectrophotometer at $660 \mathrm{~nm}$. Diclofenac sodium was used as a standard. ${ }^{18}$ The percentage inhibition of protein denaturation was calculated using the following formula. ${ }^{19}$

$$
\text { Inhibition }(\%)=\left(\mathrm{Abs}_{\text {control }}-\mathrm{Abs}_{\text {sample }}\right) \times 100 / \mathrm{Abs} \text { control }
$$

In vitro Anti-proliferative Activity

Preparation of MCF - 7 Cell culture: The MCF - 7 cell lines were cultured in Dulbeco's modified Eagle's medium (DMEM). The Medium was supplemented with $10 \%$ heat inactivated fetal bovine serum (FBS). The cell lines were subculture in cell culture flask and then incubated for 2 days at $37^{\circ} \mathrm{C}$ in a humidified $\mathrm{CO}_{2}$ incubator with $5 \% \mathrm{CO}_{2}$. The cells were observed every $24 \mathrm{hr}$ under an inverted tissue culture microscope. ${ }^{20}$ In vitro cell cytotoxicity activity (MTT assay): MTT (3-(4, 5- $\mathrm{di}-$ methylthiazol-2-yl)-2, 5-diphenyl tetrazolium bromide) is reduced by mitochondrial succinate dehydrogenase to purple coloured formazan product, which reflects the normal functioning of mitochondria and cell viability. 15000 cells per well were seeded in 96-well plates at varying cell number in $100 \mu \mathrm{l}$ of growth medium and incubated for $24 \mathrm{hr}$ in a $\mathrm{CO}_{2}$ incubator. $100 \mu \mathrm{l}$ of the medium containing the plant extract (initially dissolved in DMSO) was added and re-incubated for $48 \mathrm{hr}$ in a $\mathrm{CO}_{2}$ incubator. MTT solution was prepared as a solution of 3-(4, 5-dimethylthiazol-2-yl)-2, 5-diphenyl tetrazolium bromide $5 \mathrm{mg} / \mathrm{ml}$, pH 7.2 in phosphate buffered saline and $200 \mu$ lof this solution was added to each well. ${ }^{21}$ After $2 \mathrm{hr}$ contact with the MTT solution, blue crystals were formed. The suspension was transferred to a spectrophotometer cuvette and absorbance was measured at a wavelength of $570 \mathrm{~nm}^{22}$

\section{Statistical analysis}

The data was stated as mean \pm SD. Student's t-test was adopted to assess the significance of differences between results obtained from different samples and between results from samples and controls using the Graph
Pad Prism 7 software. A probability value of less than 0.05 will be considered as significant.

\section{RESULTS}

\section{In vitro Anti-Inflammatory Activity}

Alcoholic root extract effectively inhibits the protein denaturation. Table 1, showed the significant inhibition of $66.20 \pm 1.19 \%$ and $85.03 \pm 0.73 \%$ for the root extract and diclofenac sodium respectively at $1000 \mu \mathrm{g} / \mathrm{ml}$ concentration.

\section{Cytotoxicity Assay}

The alcoholic root extract exhibited a time and dose dependent activity and possesses moderate anti-proliferative effect against the cancerous cell lines (Table 2).

\section{DISCUSSION}

Plants are becoming possible source for phytoconstituents with diverse pharmacological activities. Documentation of such plants of probable use in medicine is of connotation. The scientific studies to work out the actual efficacy and other limitations of the drugs would definitely extend their scope for further use, if they come out to be really operative. The presently available drugs provide only symptomatic relief with many side effects. So, the goal was to discover newer drugs from herbal resources, with lesser side effects. ${ }^{2,6}$

In-vitro anti-inflammatory potential was examined by adopting protein denaturation method, in which diclofenac sodium was used as a standard. Alcoholic root extract effectively inhibits the protein denaturation. Pharmacological investigations clearly indicated that anti-inflammatory activity in many plants has been attributed to their flavonoid and phenol contents. ${ }^{23}$ Several flavonoids isolated from the medicinal plants have been discovered to possess significant anti-inflammatory activity. ${ }^{24}$ From the results obtained in the current study, it may be concluded that alcoholic root extract possesses anti-inflammatory potential, which is comparable to the synthetic anti-inflammatory agent diclofenac sodium.

\section{Table 1: Inhibition of Protein Denaturation.}

\begin{tabular}{cccc}
\hline S.No. & $\begin{array}{c}\text { Concentration } \\
(\mu \mathrm{g} / \mathrm{ml})\end{array}$ & $\begin{array}{c}\text { \% Inhibition of } \\
\text { standard (mean } \pm \\
\text { standard deviation) }\end{array}$ & $\begin{array}{c}\text { \% Inhibition of sample } \\
\text { (mean } \pm \text { standard } \\
\text { deviation) }\end{array}$ \\
\hline 1. & 100 & $74.49 \pm 0.84$ & $41.89 \pm 1.42$ \\
2. & 200 & $77.92 \pm 1.42$ & $45.73 \pm 0.46$ \\
3. & 500 & $79.58 \pm 1.24$ & $55.36 \pm 0.95$ \\
4. & 1000 & $85.03 \pm 0.73$ & $66.20 \pm 1.19$ \\
\hline
\end{tabular}

Values are expressed as mean $\pm \mathrm{SD}$. Values are significant at $p<0.05(n=6)$

Table 2: Effect of alcoholic extract of Euphorbia hirta roots on MCF-7 cell viability.

\begin{tabular}{cc}
\hline $\begin{array}{c}\text { Concentration } \\
(\mu \mathrm{g} / \mathrm{ml})\end{array}$ & $\begin{array}{c}\text { \% cell viability } \\
(\text { mean } \pm \text { standard deviation })\end{array}$ \\
\hline 0.01 & $88.61 \pm .18$ \\
0.1 & $87.29 \pm .20$ \\
1.0 & $81.43 \pm .10$ \\
10 & $61.57 \pm .16$ \\
100 & $48.08 \pm .30$ \\
\hline
\end{tabular}

Values are expressed as mean $\pm \mathrm{SD}$. Values are significant at $p<0.05(n=6)$ 
Anti-proliferative potential (in-vitro) of alcoholic root extract of Euphorbia hirta was evaluated by using MTT assay on MCF-7 cell lines. The alcoholic root extract exhibited a time and dose dependent response. As for euphorbia hirta, anti-proliferative action of roots via MCF-7 cell lines was reported for first time. Plant extracts anticancer effect is mainly found to be due to the presence of different phytochemical constituents present in the extract such as flavonoids. ${ }^{15}$ As the initial phytochemical investigation of the extract suggested the presence of chemical constituents like flavonoids in the extract and the effect of flavonoids in reducing cancer risk has been already reported in various studies., ${ }^{2,15,25}$ Results obtained from the present study, concluded that alcoholic root extract possesses prominent anti-inflammatory and moderate anti-proliferative potential.

\section{CONCLUSION}

From the results obtained, alcoholic root extract could be concluded to possess anti-inflammatory potential. Conjointly anti-proliferative potential (in-vitro) was also assessed by means of MTT assay on MCF-7 cell lines. ${ }^{26}$ The alcoholic root extract exhibited a time and dose dependent response. Biochemical mediators involved in these biological processes need to be investigated to assess the specific mechanisms of the extract tested and also to identify the possible lead molecules involved during the biological process.

Thus, in future, further studies are needed to isolate and identify the active constituents responsible for such activities.

\section{ACKNOWLEDGEMENT}

We are thankful to the management and administration of K. R. Mangalam University, Gurugram for their guidance and support for the study.

\section{CONFLICT OF INTEREST}

The authors declare no conflict of interest.

\section{ABBREVIATIONS}

DMSO: Dimethyl sulfoxide; FBS: Fetal Bovine Serum; MTT: 3-(4, 5-dimethylthiazol-2-yl)-2, 5-diphenyl tetrazolium bromide, MCF-7: Human breast cancer, SD: Standard deviation.

\section{REFERENCES}

1. Rangari VD. Pharmacognosy and phytochemistry. 1st ed. Nashik: Carrer publication; 2002. p. 67-77.

2. Rajeh MA, Zuraini Z, Sasidharan S, Latha LY, Amutha S. Assessment of Euphorbia hirta L. Leaf, flower, stem and root extracts for their antibacterial and antifungal activity and brine shrimp lethality. Molecules. 2010;15(9):6008-18. doi: 10.3390/ molecules15096008, PMID 20877206

3. Prajapati ND, Purohit SS, Sharma AK, KumarT. A handbook of medicinal plants, Agarbios, Jodhpur, India. p. 231; 2003.
4. Nadkarni KM. Indian materia medica, 4th Vol. Bombay, India: popular prakashan. p. $524 ; 1976$.

5. Kumar S, Malhotra R, Kumar D. Antidiabetic and free radicals scavenging potential of Euphorbia hirta Flower extract. Indian J Pharm Sci. 2010;72(4):533-7. doi: 10.4103/0250-474X.73921, PMID 21218075.

6. Rastogi RP, Mehrotra BN. Compendium of Indian Medicinal Plants. $3^{\text {rd }}$ Vol. 2002.

7. Anoop MV, Bindu AR. In-vitro anti-inflammatory activity studies on Syzygium zeylanicum (L.) DC leaves. Int J Pharm Res Rev. 2015;4(8):18-27.

8. Sonyot W, Lamlertthon S, Luangsa-Ard JJ, Mongkolsamrit S, Usuwanthim K, Ingkaninan K, Waranuch N, Suphrom N. In vitro antibacterial and anti-inflammatory effects of novel insect fungus Polycephalomyces phaothaiensis extract and its constituents against Propionibacterium acnes. Antibiotics (Basel). 2020;9(5):274. doi: 10.3390/antibiotics9050274, PMID 32466146.

9. Mizushima Y. Screening test for anti-rheumatic drugs. Lancet. 1966;2:443-48.

10. Abraham DJ, Hoboken NJ. Burger's medicinal chemistry and drug discoverychemotherapeutic agents. NJ: John Wiley \& Sons; 2003. p. 4-11.

11. Availablefrom:https://www.cancerresearchuk.org/about-cancer/what-is-cancer/ how-cancer-can-spread [cited 7/10/2021].

12. Jagetia GC, Rao SK. Evaluation of the antineoplastic activity of Guduchi (Tinospora cordifolia) in Ehrlich ascites carcinoma bearing mice. Biol Pharm Bull. 2006;29(3):460-66. doi: 10.1248/bpb.29.460, PMID 16508146.

13. Available from: https://www.ncbi.nlm.nih.gov/pmc/articles/PMC5075620 [cited 7/10/2021].

14. Sidambaram RR, Dinesh MG, Jayalakshmi ET. An in vitro study of cytotoxic activity of Euphorbia hirta on hep 2 cells of Human epithelioma of larynx. Int $J$ Pharm Pharm Sci. 2011;3(3):101-3.

15. Thind TS, Rampal G, Agrawal SK, Saxena AK, Arora S. Evaluation of cytotoxic and radical-scavenging activities of root extracts of Schleichera oleosa (Lour.) Oken. Nat Prod Res. 2012;26(18):1728-31. doi: 10.1080/14786419.2011.606547, PMID 21988592.

16. Harborne JB. Phytochemical methods - A Guide to modern techniques of plant Analysis. 1st ed. London, UK: Chapman \& Hall; 1998.

17. Rashmi, Gupta P. Pharmacognostical and phytochemical screening of roots of Euphorbia hirta linn. Int J Pharm Biol Sci. 2019;9(2):1480-5.

18. Mizushima $Y$, Kobayashi M. Interaction of anti-inflammatory drugs with serum proteins, especially with some biologically active proteins. J Pharm Pharmacol. 1968;20(3):169-73. doi: 10.1111/j.2042-7158.1968.tb09718.x, PMID 4385045

19. Leelaprakash G, Dass SM. In vitro anti-inflammatory activity of methanol extract of Enicostemma axillare. Int J Drug Dev Res. 2011;3.

20. Available from: https://www.ncbi.nlm.nih.gov/pmc/articles/PMC3571722 [cited 7/10/2021].

21. Available from: https://www.nature.com/articles/4500790 [cited 7/10/2021].

22. Lau CB, Ho CY, Kim CF, Leung KN, Fung KP, Tse TF, Chan HH, Chow MS. Cytotoxic activities of Coriolus versicolor (Yunzhi) extract on human leukemia and lymphoma cells by induction of apoptosis. Life Sci. 2004;75(7):797-808. doi: 10.1016/j.Ifs.2004.04.001, PMID 15183073.

23. Duke JA. Handbook of Biologically Active phytochemicals and their activities Boca, Raton, FL: CRC Press Press; 1992.

24. al-Said MS, Tariq M, al-Yahya MA, Rafatullah S, Ginnawi OT, Ageel AM. Studies on Ruta chalepensis, an ancient medicinal herb still used in traditional medicine. J Ethnopharmacol. 1990;28(3):305-12. doi: 10.1016/0378-8741(90)90081-4, PMID 2335958

25. Joshi CG, Gopal M, Byregowda SM. Cytotoxicity activity of Tragia involucrate Linn extracts. Am Eurasian J Toxicol Sci. 2011;3(2):67-9.

26. Lin CC, Cheng HY, Yang CM, Lin TC. Antioxidant and antiviral activities of Euphorbia thymifolia L. J Biomed Sci. 2002;9(6 Pt 2):656-64. doi: 10.1159/000067281, PMID 12432232. 